\title{
An Establishment Of The Role Of Private And Public Sector Interests In The Context Of Tourism Transport Planning And Development: The Case Of Malaysia
}

\author{
Sharon Cheuk, Universiti Malaysia Sabah, Malaysia \\ Janie Liew-Tsonis, Universiti Malaysia Sabah, Malaysia \\ Grace Phang Ing, Universiti Malaysia Sabah, Malaysia \\ Izyanti Awang Razli, Universiti Malaysia Sabah, Malaysia
}

\begin{abstract}
Although 90\% of the tourism industry consists of small businesses, the approach of consecutive governments in Malaysia is that tourism has reached a stage where its promotion and funding is the responsibility of the private sector. When national and regional tourist promotional boards were established, it was the intention that these would act as a vehicle for cooperation between the public and private sectors. This has proved to be extremely optimistic, with only a small number of tourism businesses actually joining in the decision-making processes of the direction for tourism development. The role of tourism development has been further undermined with the increasing rate of tourist arrivals, further implicating the control of public-sector resources, while governments place reliance on private/public partnerships as the model for the future. This research paper reports on the findings of a two-year study on the promotion of transportation in tourism development in Malaysia. It establishes the role of private and public sector interests in the context of tourism transport planning and development. A qualitative approach to in-depth interviews was conducted with respondents from the public sector (policy makers and local authority and government agency representatives) and the private sector (tour and travel agents) in Malaysia. The empirical evidence has shown that implementing stakeholders within the tourism industry are receptive to the promotion of transportation and aware of the differing roles each sector plays in the context of tourism transport planning and development. However, they do not fully exploit the complementary role played by the other sector for mutual benefit via consultations and public private partnerships at the planning stage.
\end{abstract}

Keywords: tourism, planning and development, role of public - private sector, transportation, Malaysia

\section{INTRODUCTION}

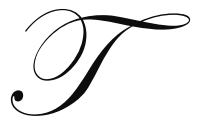

ourism was developed by the Malaysian government as a means to meet several development objectives such as increasing foreign exchange earnings, increasing employment and income and fostering regional development (Khalifah \& Tahir, 1997; Musa, 2000). In the 1970s, the Malaysian government's priority in tourism was the provision of basic tourism infrastructure, for instance highways, airports and tourist sites in each state, and occasionally took the role of entrepreneur and guarantor for overseas investment (Musa, 2000). However, tourism was only seriously identified as an industry that had the potential to stimulate the socio-economic development of the country after the mid-1980s, when severe economic recession hit most of the Asian region. In the 1980s the Malaysian government focused on promoting tourism in the private sector with incentives given to the private sector to develop accommodation, visitor centre facilities and encourage Bumiputera participation (Khalifah \& Tahir, 1997; Musa, 2000). 
Government commitment towards tourism development has been further demonstrated by the increase in funding allocations over the years. In the Second Malaysia Plan, spending on the development of tourism infrastructure and marketing and promotions amounted to RM17.2 million (Khalifah \& Tahir, 1997). For the latest Ninth Malaysia Plan covering the period 2006 - 2010, allocated spending has ballooned to RM1.8 billion, a 136\% increase over that spent in the Eighth Malaysia Plan (Economic Planning Unit Malaysia, 2006).

The main government machinery behind tourism development is the Ministry of Tourism, which was first established as the Ministry of Culture and Tourism in 1987, and further renamed as the Ministry of Culture, Arts and Tourism in 1990. The Ministry of Tourism is tasked with coordinating and implementing government policies and strategies pertaining to tourism development (Ministry of Tourism Malaysia, 2009). The Malaysian Tourism Promotion Board, more popularly known as Tourism Malaysia, serves as the main tourism promotion agency under the auspices of the Ministry of Tourism. Its main functions, in accordance with the Malaysia Tourism Promotion Board Act 1992, are: (a) to stimulate and promote tourism to and within the country; (b) to stimulate, promote and market Malaysia, internationally and domestically, as a tourist destination; (c) to coordinate all marketing and promotional activities relating to tourism conducted by any organisation, government or non-governmental agencies; and (d) to offer recommendations (and to implement or assist in the implementation) for the adoption of appropriate methods, measures and programmes to facilitate or stimulate the development and promotion of the tourism industry in Malaysia (Musa, 2000). Regional tourist promotion boards extend the functions of the Malaysia Tourism Promotion Board at the state level. It can be noted that in encouraging the coordination of tourism promotional activities, the national and regional tourist promotional boards would act as a vehicle for cooperation between the public and private sectors.

Private sector investment in tourism has not needed much encouragement. The number of hotels expanded by 51.2 percent from 2000 to 2005; travel and tour agencies increased from 1,021 in 2000 to 2,383 in 2005; and licences issued to tour coach and car rental operators increased from 18,460 in 2000 to 20,610 in 2005 (Economic Planning Unit Malaysia, 2006). The Malaysian government further accelerated private investment in the tourism industry by launching two special funds in 2001, namely the Tourism Infrastructure Fund (TIF) totalling RM700 million, and the Special Fund for Tourism and Infrastructure (Special Fund) with an initial allocation of RM400 million (Economic Planning Unit Malaysia, 2006). These funds clearly encountered a high demand, because they were increased to RM1.2 billion each in July 2005 (Economic Planning Unit Malaysia, 2006).

However, in terms of participation in the decision-making process to determine the direction of tourism development, the involvement of the private sector has been largely lacklustre, and tourism planning (including tourism transport planning and development) largely remained the domain of the public sector.

The implication of the above is significant. Tourist arrivals to Malaysia have dramatically increased over the past decade, with an increase of 300\% from 5.5 million in 1998 to 22 million in 2008 (Tourism Malaysia, 2008). A year-on-year increase was noted from 2003 onwards (Tourism Malaysia, 2008), fueled in part by the Visit Malaysia Year campaign in 2007. Forecasted tourist arrivals for 2009 still remained at 20 million despite the current global economic downturn (Mehta, 2009). This increasing rate of tourist arrivals has further implicated the control of public-sector resources in Malaysia. This is because the national and regional transport infrastructure need to serve both the local residents (for commuting and non-tourist travel) and the tourist consumers (for recreational travel); therefore it is essential that transport policies and planning take into consideration the requirements of both parties (Page, 1999). When tourism causes an overload on public resources due to the inadequacy of the national infrastructure, capacity problems and bottlenecks may develop (Page, 1999), as can be seen in the case of China (Gormsen, 1995).

The conflict of interest between public and private sectors in tourism development has been welldocumented (Holloway \& Taylor, 2006; Page, 1999; Wall \& Mathieson, 2006). Private enterprise, unfettered, will tend to seek short-term profit maximisation and invest in the marketing and promotion of currently popular tourist destinations over the the development of new and untried destinations. A common example is the marketing of popular air routes in accordance with the load factor; routes between capital cities with numerous attractions are more marketable. On the other hand, the public sector is duty-bound, inter alia, to ensure that public resources are developed, upgraded and maintained for the benefit of the general tax-paying public, and not only the visiting 
tourists. The government has to balance, therefore, the use of tourism as a driver of economic development with the supervision and control of its public resource consumption. The private sector also has to walk the fine line between generating a decent profit from tourism-related commercial activities and over-exploiting a tourism destination/product to the extent that it is not sustainable in the long term. The latter would be tantamount to killing the proverbial egg-laying goose, and does not make economic sense for the private sector.

There is, therefore, a need for an avenue whereby the public and private sectors are brought together for the achievement of common goals, to the mutual benefit of both parties. In this respect, it has been argued that tourism has now reached a stage where the public sector can no longer be the sole guardian and promoter of tourism transport planning and development, and the importance of the involvement of private sector in planning and development is paramount. Tourism planning and policy-making in the 1990s, in general, became more participation-led whereby collaborative planning (Healey, 1997), communicative processes (Forester, 1989; 1993) and consensus building (Innes, 1996) were emphasised. Healey (1997) asserts that the success of planning efforts should be assessed by whether relationships between stakeholders were forged, whether trust and understanding flowed between the said stakeholders, and in turn generated support for the subsequent policies and strategies formed. Such planning would therefore be more relevant and have the "capacity to endure over time" (Healey, 1997, p.71). This is in line with the observation of Wall and Mathieson (2006) of developed countries, where an increased emphasis is now given on the process of development with opportunities provided for public input and stakeholder involvement. However, it would seem that public involvement in planning seldom occurred in developing countries (Wall \& Mathieson, 2006), of which Malaysia is one.

Public-private partnerships (PPPs) are now widely regarded to be the operative model for the future. In the UK, for example, the Tourism Review and Implementation Group was created with the aim of holding an annual conference which would bring together interested parties within the industry, both public and private (Holloway \& Taylor, 2006). Another example of a successful PPP is related to the upcoming London Olympic Games 2012 (Bond \& O'Flynn, 2005; Holloway \& Taylor, 2006). The PPP concerned won the bid to host the said Games in London because it was able to cite the regeneration of one of Britain's poorest areas and the increase in permanent employment for local residents resulting from the construction of the relevant sports facilities as convincing factors.

In the Malaysian context, one documented PPP which has been considered successful has been the provision of home ownership to the urban poor in Kuala Lumpur, Malaysia by a local authority and a private developer (Abd Aziz, Hani \& Musa, 2007).

It can be seen from the foregoing that a PPP aims to benefit both public and private sector interests. Indeed, Jeneleniewski (1999) described the characteristics of PPPs as: (a) involving one or more public authorities; (b) involving one or more private partners; (c) co-operation to fulfill a mutually agreed objective through a specific organisational framework set up by the parties involved; (d) each party retains its own identity; (e) there is an input of resources by the parties concerned; and (f) parties bear the risk of the project together and share profits, according to their possibilities. Abd Aziz, Hani and Musa (2007) further note that PPP participants complement each other, in which "the strengths and weaknesses of each partner are offset against those of the other in generating developments that merge the best quality of each". They also note that PPPs do not infer that the participants involved put aside self-interest; rather, PPPs provide a long term framework within which such interest is protected and promoted.

PPPs involve a continuing public-private dialogue on what needs to be done to promote their realisation, and a supportive policy and institutional framework (United Nations, 1997).

In theory, the PPP appears to be a sustainable and exploitable model; the private sector can maintain its profit-making agenda and, at the same time, give feedback on the operation of policies, rules, regulations and procedures which affect their economic performance. They can also make suggestions for improvement. The public sector clearly benefits from the buy-in of the private sector into stated public sector objectives.

In practice, however, it is unclear how the PPP model can be applied to tourism transport planning and development in Malaysia. 


\section{RESEARCH OBJECTIVES AND QUESTION}

In our research, we examine the roles of the public and private sector interests in the context of tourism transport planning and development as perceived by the relevant representatives. We then consider the applicability of the PPP framework, be it on a small or large scale, amongst the tourism transport players.

Hence, the research question is as follows: What are the respective roles of the private and public sector interests in the context of tourism transport planning and development, and are they aware of and understand these roles?

In attempting to answer this question, the research team conducted a two-year study on the promotion of transportation in tourism development in Malaysia.

\section{METHODOLOGY}

A qualitative approach, in the form of in-depth interviews, was adopted to address the research objectives. Such an approach was deliberately chosen as it offered the researcher adaptability in data collection, whereby ideas can be followed up on, responses can be further probed and motives and feelings can be further explored. As the interviews were conducted by a team of researchers with respondents at various locations at different times, standard semi-structured questionnaires were used to ensure coverage of the research objectives; they acted only as an interviewing guide and were not directly administered to the respondents. Leeway was given to the respondents to expand on their views as necessary, with minimal interruption from the interviewers. Interviewers would provide further clarification or prompt the respondents with suggestions or hints only when respondents were unclear about what was asked. In return, interviewers would also seek further clarification if the answers given were vague. Interviewers would also probe further if any interesting areas or issues emerge.

Pilot testing was performed to test the reliability and validity of the semi-structured questionnaires. Questions and instructions were tested for clarity; questions which did not yield usable data were either removed or rephrased accordingly.

A total of 64 in-depth interviews were conducted with respondents from the public sector (policy makers and local authority and government agency representatives) and the private sector (tour and travel agents) in Malaysia. These respondents were selected from four cities within Malaysia: Kota Kinabalu, Kuching, Penang and Kuala Lumpur. The said cities were chosen based on multiple considerations: the presence of international air transport hubs, destination attractions and the level of tourism activities in the said cities, which are high.

Interview appointments were scheduled via phone calls and follow-up letters or emails. The interviews lasted an average of 45-60 minutes. Given the qualitative nature of the interviews, there was no predetermined sample size. Data was collected over a nine-month period from June 2008 to March 2009. Each interview was preceded by an introduction about the objectives of the research project.

\section{DATA ANALYSIS}

A total of 64 semi-structured questionnaires and interview transcripts were analysed using a interpretative phenomenological analysis approach, which involves trying to understand lived experience and how respondents themselves make sense of these experiences (Smith, 2004). Coding was performed based on meaningful key words, phrases or sentences that generated themes related to the research objective.

We asked the respondents the following questions: (a) Whether, in their opinion, the private sector promotes transportation; (b) If so, who are the private sector parties; (c) In what way is the private sector involved; (d) Is it important for the private sector to play a role in the promotion of transportation in tourism development; and (e) What does the respondent see as his/her role as a public/private sector in the planning and development of transportation. 


\section{FINDINGS AND DISCUSSION}

From our findings, we noted that $93.6 \%$ of the public sector and $80.9 \%$ of the private sector were of the opinion that the private sector does promote transportation, although, as one respondent qualified, they needed to be first incentivised to do so by the government.

The public sector generally perceived the private sector parties to be private operators such as airlines, tour operators (who operate tour coaches), transportation companies (such as car rentals, bus companies, taxi operators and riverboat/cruise ship operators) and transportation associations. Owners of tourism products such as resorts and hotels are also involved as they generally provide transportation for the convenience of guests.

Almost all the respondents (98.4\%) agreed that it is important for the private sector to play a role in the promotion of transportation in tourism development. One respondent was of the opinion that the private sector comprise mainly of users, and therefore they would better understand users' needs. According to the respondents, the private sector is involved as investors, promoters of other transportation companies, providers of a linkage service and as providers of opinions and feedback to the public sector. As investors, the private sector may invest funds in transport vehicles and infrastructure. Sometimes the private sector act as operators and be responsible for maintenance of vehicles and the related infrastructure. One respondent highlighted the importance of the private sector contributing, not just funds, but ideas, creativity and drive to see through business initiatives to the micro level. As promoters of the use of transportation companies, the private sector may help to sell tickets to buses and coaches. Usually this is done by tour agencies and operators. The private sector could also act as providers of a linkage service between other modes of transportation. Some examples of such linkage services are the availability of taxis and buses between a cruise ship/airport and the intended land destinations, and between river transportation and the interior. Such services, usually private in nature, often create a transportation linkage where there is no other alternative.

The private sector parties who are part of tourist associations may also call for meetings or dialogues with a public sector party when issues or problems arise, such as the lack of facilities available. They may also have dialogues with government tourism authorities and other tourism players to know how to better promote trade or passenger volume. However, some private sector respondents highlighted a lack of dialogue with the government authorities and that their views were not often actively sought for. One respondent, the representative of a tourist association, said that the government often did not consider the need to invite the opinions of the said association in the consideration of a new airport. The response of the tourist association was to volunteer (to the government) to attend all consultative meetings to provide feedback and opinions. Another respondent, a government agency, also highlighted the lack of dialogue with another government ministry on the issues of tourism planning and development.

As for the perception of roles by both public and private sectors, the public sector viewed its role to be: (a) a provider of transportation infrastructure, funds and incentives to promote tourism transportation; and (b) to be responsive to the problems faced by the private sector. In the provision of transportation infrastructure, public sector respondents further defined their roles to include the planning and the expansion of infrastructure to cater for future growth and needs. One respondent highlighted that planning efforts took into account manpower needs and environmental concerns. Another respondent said that planning and development needed to be in tandem with the population growth to avoid congestion, especially in urban areas. Funds and incentives given by the private sector to promote tourism transportation would be in the form of soft loans and subsidies.

Ninety-nine percent of the private sector respondents were of the opinion that their role was to assist the government in the promotion of tourism transportation. Specifically, the private sector viewed its role as a provider of input and feedback to the government and the relevant authorities, and as a promoter of tourism transportation, such as by offering special fares and by differentiating tourism-related transportation products. An example given by a cruise operator respondent was that special fares are offered for early birds or for different categories of travellers (e.g. senior citizens), and cruise itineraries are changed to attract repeat visitors. 
During the course of this study, the research team conducted a mid-term workshop to consolidate the preliminary findings obtained. Workshop participants comprised of local authority representatives and private tour operators. One of the discussion points that emerged was that there was a need for a smart partnership and synergy creation between the local authorities and the private sector. One offered suggestion was the setting up of relevant committee structures by the local authorities to facilitate tourism events or discuss tourism issues, with participation by the tour operators. The tour operators could also be a source of funds for certain tourism events or act as pressure groups for the building of certain facilities, which would benefit both tourists and local residents. That would in turn aid the local authority representatives in discharging their duties. At the end of the workshop, both the local authority representatives and tour operators appeared to realise the value and benefit of having an avenue (such as the workshop itself) for discussion and feedback, as many issues could be freely discussed and suggestions offered.

The empirical evidence has shown that implementing stakeholders within the tourism industry are receptive to the promotion of transportation. They appear to be aware of the differing roles played by each sector in the context of tourism transport planning and development; the public sector is responsible for planning and development, especially that of infrastructure, the provision of incentives to the private sector and policy-making, whereas the role of the private sector is that of a growth driver. However, it would appear that both sectors do not fully exploit this fact. For instance, the private sector is aware that the public sector is responsible for infrastructure, but they do not participate actively in the planning and development of it, especially when invited to workshops seeking feedback and opinions on a proposed development or master plan. On the other hand, the public sector is aware of its own role in planning and development, and that the private sector's role is to invest and promote, but they do not pursue the seeking of private sector feedback aggressively so that the subsequent planning and development will take into consideration the latter's needs and requirements.

A specific example of this in Malaysia is the Low Cost Carrier Terminal (LCCT), which was said to be built without prior consultation with the public, and with Air Asia (Malaysia's main low cost carrier) (Malaysiakini, 2006). Hence, the LCCT, which was used mainly by Air Asia, was allegedly not built according to Air Asia's specifications - and when it opened for operations, problems were experienced with passenger flows (Air Asia, 2008a).

A recent issue involved, again, Air Asia and Malaysia Airports Berhad. Air Asia proposed a new air terminal at KLIA-East at Labu, Negeri Sembilan, some $9 \mathrm{~km}$ from the current international airport (KLIA), citing reasons of, amongst others, increased capacity and better connectivity and location (Air Asia, 2008). The financing of the said project would be funded via a Private Finance Initiative and not involve public spending. This was countered with the fact that there would be two terminals, implying that there would be duplication of services. Also, air traffic would be diverted away from KLIA and jeopardise its position as an international air hub - which would be against national interest ("KLIA-East @ Labu", 2008). This issue was played out in the media, with Malaysia Airports issuing a series of press statements explaining its position. Air Asia countered this by posting justifications for the new air terminal on a micro-site (Air Asia, 2008b). At the time of writing, this issue is still unresolved.

The above two issues highlight again the value of using a PPP as a platform for both public and private sectors to co-operate on a project for mutual benefit, at the planning stage when specifications are set.

\section{CONCLUSIONS, CONTRIBUTIONS AND SUGGESTIONS FOR FUTURE RESEARCH}

The purpose of the paper was to establish the roles of the public and private sectors in the context of tourism transport planning and development. Based on a two-year study, the findings seem to suggest that implementing stakeholders within the tourism industry are receptive to the promotion of transportation and aware of the differing roles each sector plays in the context of tourism transport planning and development. However, they do not fully exploit the complementary role played by the other sector for mutual benefit, by engaging in consultations and public private partnerships at the planning stage. In summary, the public sector does not actively seek out the opinions of the private sector, and the private sector, on an individual basis, does not actively seek to voice out their opinions to the public sector. 
The paper contributes to the existing literature on the promotion of transportation in tourism planning and development which has not been well-researched for Malaysia. It is envisaged that the findings from this study can be used as inputs into the government policy-making process, and can be utilised by the public sector in its different forms: local authorities, ministries (tourism-related or otherwise), the Malaysian Tourism Promotion Board.

The recommendation to the public sector bodies is to seek the views of different stakeholders in tourism transport planning and development via formal and informal means. Such avenues would do away with the need for public lobbying. Such avenues may include discussion groups, dialogues and focus groups. On a larger scale, PPPs come into play, and the government could educate the private sector on the benefits of PPPs.

Future research avenues could include the study of the motivations of private sector parties to investigate why they do not participate in the platforms available for partnerships. This could involve an investigation into their limitations and challenges, which may include factors such as previous bad experience in dealing with the public sector/government or the perception of too much government bureaucracy. The private sector may have other criticisms of the government and civil servants, as highlighted by Dredge and Jenkins (2007): (a) civil servants do not look after public interests, but rather, perform their duties based on personal agenda such as reward, power, prestige and job security (Lane, 2000); and (b) governments do not cater for the greater public good and powerful interests influence agendas and decision-making. Parsons (1995) also observed that public choice theorists were of the opinion that governments, like individuals, were motivated by self-interest and seek to maximise their own benefits, as well as that of their supporters'. Hence, the private sector may assume that their interests will have to be put aside in subordination to government policy, and perceive that the government only pays lip service to the needs of the private sector. Dredge and Jenkins (2007, p.285-286) even went as far as to state that "governments have become canny in reproducing the sustainable development rhetoric without actually effecting fundamental policy shifts at a regional level".

Another reason for the private sector's hesitation could be a lack of understanding of the the benefits of participating in a PPP.

\section{LIMITATIONS}

The limitation of the paper lies in the research design which is exploratory and qualitative in nature, which implies that findings were not generalisable. For better validation of the findings and research reliability, data collection could be extended to the other states and cities in Malaysia. Comparative work in a similar context in different locations and countries would prove beneficial in this respect.

Also, a sequential exploratory strategy (a mixed method approach whereby quantitative analysis follows after qualitative) could be employed, whereby qualitative data collected can be further explored for distribution of a phenomenon observed, or for testing emergent theory arising from the qualitative phase (Creswell, 2003).

To strengthen the findings obtained, the study originally intended to re-interview the public sector respondents at the departmental level. In other words, respondents from the same public sector agency would be collectively interviewed and the findings therefrom would be at the agency/ministry level. This would highlight areas whereby individual opinion differs from that of the collective opinion of the agency/ministry. However, it was felt that the implementation of this would have practical difficulties. In lieu of the foregoing, the research team has planned to hold a workshop to present the research findings to-date to the interviewed respondents. The ensuing discussion and conclusion amongst the said respondents should then form a collective opinion for their respective agencies/ministries.

\section{ACKNOWLEDGEMENT}

The empirical findings of this paper are part of a research project on the promotion of transportation in tourism development in Malaysia. This is funded by the Ministry of Science and Technology under its Science Fund Project No: 06-01-10 SF0057 from 2007-2009. The authors hereby express their sincere gratitude to the Ministry of Science and Technology (Malaysia), for the funding of this research. 


\section{AUTHOR INFORMATION}

Sharon Cheuk is an Auditing lecturer at the School of Business \& Economics, Universiti Malaysia Sabah (UMS). She read her first and masters degrees at De Montfort University, United Kingdom. She joined Ernst \& Young in 1995, and serviced a portfolio comprising clients in the manufacturing, engineering, construction, financial services, hospitality, tourism, timber and plantation industries. Sharon was also extensively involved in consultancy, financial monitoring and due diligence assignments, and coordinated the firm's staff training as well as served as a key trainer. Sharon joined UMS in 2004, and currently contributes her expertise to multidisciplinary team research. She has participated in research with the Malaysian Ministry of Science, Technology and Innovation and Malaysian Accounting Research and Education Foundation.

Janie Liew-Tsonis is Associate Professor at the School of Business and Economics, Universiti Malaysia Sabah (UMS); Janie is under the Tourism Program and specializes in Ecotourism, Community Development, Biodiversity and Park Management. Her current research interests is in the linkage of policies to sustainable development and how the usage of data in exercising judgment can minimize risks in its implementation on the ground. Janie has a $\mathrm{PhD}$. in Biodiversity Management, MSc. In Business Administration and a BSc. In Economics, and economic linkages with the natural environment is where she feels most comfortable. Her performance results include a good partnership with the private/public sectors especially where socio-economic and environmental emerging trends and conditions are concerned.

Phang Ing Grace is a lecturer at the School of Business \& Economics, Universiti Malaysia Sabah (UMS), where she currently serves as a lecturer in the Marketing Program. Her areas of specialty are Strategic Marketing, Sales Management and Services Marketing. After receiving her first degree in Marketing from Universiti Kebangsaan Malaysia and master degree from Universiti Putra Malaysia, she moved on to Singapore to pursue a career in the shipping and logistic industry. In 2004, she joined UMS at Kota Kinabalu. Her research interests are services, branding strategy and advertising. She has participated in research with the Malaysian Ministry of Science, Technology and Innovation, Ministry of Sabah Industrial Development, UMS Orchid Centre, MS Smart Recycling (M) Sdn Bhd and also Worldwide Fund for Nature (Sabah). She has also published in a number of journals such as Journal of Contemporary Reesearch in Business, International Business \& Economics Research Journal, Journal Kemanusiaan, International Journal of Business Society (IJBS), UNITAR E-journal and Anamalai Business Review.

Izyanti Awang Razli is a lecturer and the Head of the Hotel Management Program at Universiti Malaysia Sabah. Izyanti graduated from Universiti Technology Mara with a diploma and first degree before completing her masters degree in International Tourism and Hospitality Management at Griffith University, Australia. Her areas of specialty are Housekeeping Management, Hotel Operation and Accommodation Management. She has participated in research with the Malaysian Ministry of Science, Technology and Innovation and have received a Fundamental Research Grant from the Ministry of Higher Education, Malaysia.

\section{REFERENCES}

1. $\quad$ Abd Aziz, W.N.A.W., Hani, N.R. \& Musa, Z.N. (2007). Public-private partnerships approach: A success story in achieving democracy in the home ownership for urban inhabitants in Kuala Lumpur, Malaysia. In M. Schrenk, V. V. Popovich \& J. Benedikt (Eds.), REAL CORP 007: To Plan Is Not Enough: Strategies, Plans, Concepts, Projects and their successful implementation in Urban, Regional and Real Estate Development (pp. 159 - 165). Wien/Schwechat: CORP.

2. AirAsia, The Justification. (2008a). Retrieved March 15, 2009 from http://www.airasia.com/kliaeast/justification.html

3. AirAsia, Why KLIA-East. (2008b). Retrieved March 15, 2009 from http://www.airasia.com/kliaeast/whykliae.html

4. Bond, P. \& O'Flynn, D. (2005, August 2). London Olympics 2012: corporate greed and privatisation. World Socialist Web Site. Retrieved April 6, 2009, from http://www.wsws.org/articles/2005/aug2005/olym-a02.shtml

5. Creswell, J.W. (2003). Research Design: Qualitative, Quantitative and Mixed Method Approaches (2 ${ }^{\text {nd }}$ ed.). US: Sage Publications. 
6. Dredge, D. \& Jenkins, J. (2007). Tourism planning and policy. Queensland, Australia: John Wiley \& Sons.

7. Economic Planning Unit Malaysia. (2006). Ninth Malaysia Plan, Realising Tourism Potential. Retrieved April 5, 2009, from http://www.epu.gov.my/rm9/english/Chapter8.pdf

8. Forester, J. (1989). Planning in the Face of Power. Berkeley, CA: University of California Press.

9. Forester, J. (1993). Critical Theory, Public Policy and Planning Practice: Toward a Critical Pragmatism. Albany, NY: State University of New York Press.

10. Gormsen, E. (1995). International tourism in China: its organisation and socio-economic impact. In A. Lew \& L.Yu (Eds.) Tourism in China: Geographical, Political and Economic Perspectives (pp. 63 - 88).

Colorado: Westview Press.

11. Healey, P. (1997). Collaborative Planning: Shaping Places in Fragmented Societies. London: Macmillan.

12. Holloway, J.C. \& Taylor, N. (2006). The Business of Tourism ( $7^{\text {th }}$ ed.). England: Pearson Education Limited.

13. Innes, J.E. (1996). Planning through consensus building: A new view of the comprehensive planning ideal. Journal of the American Planning Association, 62(4), 460-473.

14. Introduction to the Ministry of Unity, Culture, Arts and Heritage. Retrieved March 25, 2009, from http://www.heritage.gov.my/about/pengenalan/?c=6

15. Jeneleniewski, M. (1997) Public/private partnership: Who is afraid of public private partnerships? Paper presented at a workshop on Inner City Development in Transitional Economies, at the Institute of Housing Studies, Rotterdam. Retrieved April 6, 2009 from http://programm.corp.at/cdrom2007/archiv/papers2007/corp2007_ABD.pdf

16. Khalifah, Z. \& Tahir, S. (1997). Malaysia: tourism in perspective. In F. Go \& C.L. Jenkins (Eds.) Tourism and Economic Development in Asia and Australasia (pp. 176-196). London: Cassel.

17. KLIA-East @ Labu. (2009, February 26). In Wikipedia, the free encyclopedia. Retrieved March 14, 2009, from http://en.wikipedia.org/wiki/KLIA_East_@_Labu

18. Lane, J. (2000). The Public Sector: Concepts, Models and Approaches. London: Sage.

19. Low Cost Carrier Terminal a step backward. (2006, March 17). Malaysiakini. Retrieved April 3, 2009 from http://www.malaysiakini.com/letters/48492

20. Malaysia Tourism Promotion Board Act 1992. Retrieved April 6, 2009 from http://www.agc.gov.my/agc/oth/Akta/Vol.\%2010/Act\%20481.pdf

21. Mehta, M. (2009, March 15). Tourism Malaysia Optimistic About Tourist Arrivals. Bernama (Malaysia). Retrieved April 5, 2009, from http://www.bernama.com/bernama/v5/newsgeneral.php?id=396348

22. Ministry of Tourism Malaysia Corporate Website, Profile Section. (2009). Retrieved April 6, 2009 from http://www.motour.gov.my/index.php/kem_profil.html

23. Musa, G. (2000). Tourism in Malaysia. In C.M. Hall \& S. Page (Eds.) Tourism in South and South-East Asia: Issues and Cases (pp. 144-156). Oxford, England: Butterworth Heinemann.

24. Page, S.J. (1999). Transport and tourism. England: Pearson Education Ltd.

25. Parsons, W. (1995). Public Policy: An Introduction to the Theory and Practice of Policy Analysis. Aldershot: Edward Elgar.

26. Smith, J.A. \& Osborn, M. (2004). Interpretative phenomenological analysis. In G. Breakwell (Ed.) Doing Social Psychology (pp. 229-254). Oxford: Blackwell.

27. Tourism Malaysia Corporate Website, About Us Section. Retrieved March 25, 2009, from http://www.tourism.gov.my/corporate/aboutus.asp

28. Tourism Malaysia Corporate Website, Research Section. Retrieved April 5, 2009, from http://www.tourism.gov.my/corporate/research.asp

29. United Nations. (1997). Public-private partnerships: The enabling environment for development (ST/SG/AC.6/1997/L/6). Retrieved April 5, 2009 from http://unpan1.un.org/intradoc/groups/public/documents/UN/UNPAN000727.pdf

30. Wall, G. \& Mathieson, A. (2006). Tourism: Changes, Impacts and Opportunities. England: Pearson Education Ltd. 


\section{NOTES}

